\title{
ARTIGO
}

do https://doi.org/10.22481/praxisedu.v16i37.6166

\section{USING INTERACTIVE TECHNOLOGIES IN DEVELOPING A CULTURE OF COOPERATION AMONG STUDENTS OF NON-LINGUISTIC HIGHER EDUCATION INSTITUTIONS}

\author{
USO DE TECNOLOGÍAS INTERACTIVAS EN EL DESARROLLO DE UNA CULTURA \\ DE COOPERACIÓN ENTRE ESTUDIANTES DE INSTITUCIONES DE EDUCACIÓN \\ SUPERIOR NO LINGÜÍSTICAS
}

USO DE TECNOLOGIAS INTERATIVAS NO DESENVOLVIMENTO DE UMA CULTURA DE COOPERAÇÃO ENTRE ESTUDANTES DE INSTITUIÇÕES DE ENSINO SUPERIOR NÃO-LINGUÍSTICO

Avgustina Vasilievna Ivanova Ammosov North-Eastern Federal University - Russia

Lena Anatolievna Grigorieva Ammosov North-Eastern Federal University - Russia

Oksana Nikolaevna Ivanova

Yakutsk State Agricultural Academy - Russia

Natalia Vitalievna Lysanova Ammosov North-Eastern Federal University - Russia

Lyudmila Alekseevna Gavrilieva

Ammosov North-Eastern Federal University - Russia

\begin{abstract}
This study inquired into the problems related to the culture of cooperation among students of non-linguistic higher education institutions and the use of interactive technologies as a solution to these problems. The relevance of the research lies in its illumination of the contradictions among the need to build communication environments that correspond with the transformation and modernization of Russian education in the Russian Federation, the insufficient theoretical elaboration of this issue, the new requirements in the field of education (Federal Law on Education in the Russian Federation as of December 29, 2012, No. 273-FZ (as amended on December 29, 2017), National Doctrine of Education of the Russian Federation until 2025, Federal State Educational Standard for Higher Education), and the inadequate preparedness of students to be subjects of their development in innovative educational contexts. This research was aimed at theoretically justifying the development
\end{abstract}


of a cooperative culture among students using interactive technologies. Its methodological foundations were the provisions and principles of personality-oriented, competency-based approaches and the underpinnings of intercultural competence. The study's theoretical significance is reflected by (1) its integration of pedagogical technologies on the basis of the cultivation of desired educational situations and the implementation of educational technologies in collaboration with interactive innovations and by (2) the transition from informational and explanatory education to the innovatively effective adoption of interactive technologies in the educational process, which also involves developmental and personal orientations. The research's practical significance lies in its development and organization of experimental work on the evolution of the aforementioned cooperative culture. In the experiment, interactive pedagogical technologies for English teaching, such as case methods, project approaches, role play, business-oriented games, and debates were modified and tested. The ways by which these technologies can be effectively used in higher education institutions were formulated, thereby enabling students to cultivate business collaboration skills, which are important for their future professional careers.

Keywords: Innovation; Teaching Methods; Teamwork; Intercultural Competence; Motivation; Communicative Tolerance.

Resumen: En este estudio se investigaron los problemas relacionados con la cultura de cooperación entre los estudiantes de las instituciones de educación superior no lingüísticas y el uso de tecnologías interactivas como solución a estos problemas. La pertinencia de la investigación radica en la aclaración de las contradicciones entre la necesidad de construir entornos de comunicación que correspondan a la transformación y modernización de la educación rusa en la Federación de Rusia, la insuficiente elaboración teórica de esta cuestión, las nuevas exigencias en el ámbito de la educación [Ley Federal de Educación de la Federación de Rusia del 29 de diciembre de 2012, No. 273-FZ (según lo estipulado en una enmienda del 29 de diciembre de 2017), la Doctrina Nacional de la Educación de la Federación de Rusia hasta 2025, la Norma Federal Estatal de Educación Superior], y la insuficiente preparación de los estudiantes para ser sujetos de su desarrollo en contextos educativos innovadores. Esta investigación tenía como objetivo justificar teóricamente el desarrollo de una cultura de cooperación entre los estudiantes que utilizan tecnologías interactivas. Sus fundamentos metodológicos fueron las disposiciones y principios de los enfoques orientados a la personalidad y basados en la competencia, así como los fundamentos de la competencia intercultural. El significado teórico del estudio se refleja en (1) su integración de tecnologías pedagógicas sobre la base del cultivo de situaciones educativas deseadas y la implementación de tecnologías educativas en colaboración con innovaciones interactivas y en (2) la transición de la educación informativa y explicativa a la adopción innovadora y efectiva de tecnologías interactivas en el proceso educativo, que también implica orientaciones de desarrollo y personales. La importancia práctica de la investigación radica en el desarrollo y la organización del trabajo experimental sobre la evolución de la cultura de cooperación antes mencionada. En el experimento se modificaron y probaron tecnologías pedagógicas interactivas para la enseñanza del inglés, tales como métodos de casos, enfoques de proyectos, juegos de rol, juegos orientados a los negocios y debates. Se formularon las formas en que estas tecnologías pueden ser utilizadas eficazmente en las instituciones de educación superior, permitiendo así a los estudiantes cultivar habilidades de colaboración empresarial, que son importantes para sus futuras carreras profesionales.

Palabras clave: Innovación; Métodos de enseñanza; Trabajo en equipo; Competencia intercultural; Motivación; Tolerancia comunicativa.

Resumo: Este estudo investigou os problemas relacionados com a cultura de cooperação entre estudantes de instituições de ensino superior não linguístico e o uso de tecnologias interactivas como solução para estes problemas. A relevância da pesquisa reside na iluminação das contradições entre a 
necessidade de construir ambientes de comunicação que correspondam à transformação e modernização da educação russa na Federação Russa, a insuficiente elaboração teórica desta questão, as novas exigências no campo da educação [Lei Federal sobre Educação na Federação Russa a partir de 29 de dezembro de 2012, No. 273-FZ (conforme estipulado numa emenda em 29 de dezembro de 2017), a Doutrina Nacional de Educação da Federação Russa até 2025, a Norma Federal Estadual de Educação Superior], e a preparação inadequada dos estudantes para serem sujeitos do seu desenvolvimento em contextos educacionais inovadores. Esta pesquisa teve como objetivo justificar teoricamente o desenvolvimento de uma cultura cooperativa entre estudantes que utilizam tecnologias interativas. Seus fundamentos metodológicos foram as disposições e os princípios de abordagens orientadas para a personalidade, baseadas na competência e os fundamentos da competência intercultural. O significado teórico do estudo reflete-se por (1) sua integração de tecnologias pedagógicas a partir do cultivo de situações educacionais desejadas e da implementação de tecnologias educacionais em colaboração com inovações interativas e por (2) a transição da educação informativa e explicativa para a adoção inovadora e eficaz de tecnologias interativas no processo educacional, o que envolve também orientações de desenvolvimento e pessoais. O significado prático da pesquisa reside no seu desenvolvimento e organização de trabalhos experimentais sobre a evolução da cultura cooperativa acima mencionada. Na experiência, foram modificadas e testadas tecnologias pedagógicas interativas para o ensino do inglês, tais como métodos de caso, abordagens de projetos, jogos de papéis, jogos de negócios e debates. Foram formuladas as formas pelas quais estas tecnologias podem ser utilizadas eficazmente nas instituições de ensino superior, permitindo assim aos estudantes cultivar competências de colaboração empresarial, que são importantes para as suas carreiras profissionais futuras.

Palavras-chave: Inovação; Métodos de ensino; Trabalho em equipe; Competência intercultural; Motivação; Tolerância comunicativa.

\section{Introduction}

The modernization of educational content in the Russian Federation at the present stage of societal development is unconnected to innovative processes in the organization of foreign language teaching. Amid this backdrop, the country's introduction of state standards for general education implies the need to use inventive communicative pedagogical technologies that contribute to the development of student personalities and the discovery of their creative potential, cognitive ability, and competence for team work. According to Khutorskoy (2005), an innovative educational environment is a setting in which pedagogical innovations are implemented. The purpose of using interactive pedagogical technologies is to stimulate motivation and develop a culture of cooperation among students. As explained further by Nelunova (2014), an inventive educational atmosphere is one that also includes a multimedia educational environment (MEE) — an informational setting where students interact with the outside world through open intelligent systems (the Internet, educational systems for creating Internet-based projects, distance educational courses, etc.), which are grounded 
largely in multimedia technology. Adding to these insights, Barakhsanova and Barakhsanov (2018) investigated the necessity of preparing students for the use of e-education technologies. The authors considered the effective development of a culture of cooperation among students of non-linguistic universities through interactive pedagogical technologies, such as project-based education, collaborative education, and case studies. This culture can be effectively fostered under the following conditions:

1. The development of a culture of cooperation using interactive pedagogical technologies is supported through a mastery of basic methods, means of information management, and the ability to work with information in global computer networks in the course of professional activities.

2. A culture of cooperation develops while acquiring proficiency in working in a team.

3. A student is aware of the role and importance of a foreign language in ensuring his/her effective participation in professional activities.

On the basis of the main goal of the research, the following objective were pursued:

1. To analyze interactive pedagogical technologies

2. To adapt such technologies for the development of communication skills among students of non-linguistic universities.

\section{Literature Review}

Modern conditions in the labor market are prompting changes to educational systems. Employers require graduates to have skills such as team spirit, resilience against stress, the desire to easily establish contact with the outside world, and empathy (Abd \& Behadili, 2019). The development of a culture of student cooperation through interactive pedagogical technologies was chosen as the issue for investigation because of the necessity to immediately create conditions for the formation of communicative competencies that help students unlock their potential to become promising employees in the future. One cannot but agree with Foster and Yaoyuneyong (2016), who asserted that students who are well-prepared for practical work and have well-formed cooperative skills can rapidly adapt to changing market conditions. 
Given changing requirements for the labor force, Rogers (1988), Vygotsky (2019), and many other prominent researchers put forward the use of a personality-oriented approach in education. Others, such as Zimnyaya (2006), Verbitsky (2004), and Ivanova, Skryabina and Darbasova (2019) advocated a competency-based approach, whose main provisions define the formation of a "system of competencies" as the desired goal and result. Meanwhile, outstanding scientists, such as Zimnyaya (2006) and Ter-Minasova (2000), explored the role of a foreign language in the formation of intercultural competence and a culture of cooperation, while Richards and Rodgers (1986) devoted their work to the need for communicative practice. The linguistic self-determination of personality was investigated by Nikolaeva and others (2016).

Many scientists have introduced the definitions of the concept of "pedagogical technology" such as Bespalko (1989), Klarin (1998), Selevko (1998), Bordovskaya, Kostromina and Darinskaya (2020) and others.

According to Bordovskaya, Kostromina and Darinskaya (2020), "pedagogical technology" is a system of actions by a teacher with the attributes of technology. When describing it, a project of the pedagogical activity - the pedagogy of the whole process in an educational institution-emerges.

Smolkin (1991) considers various approaches to the classification of active education methods, which is based on a sign of the imitation of the context of professional activity, and its model representation in education.

Thus, various innovative methods of teaching students can be noted; in particular, problem and game technology, the technology of collective and group activity, simulation methods of active education, methods for analyzing specific situations, project methods, education in collaboration, and others (Al-Ameedi, Ibrahim \& Nayef, 2019). As regards the teaching of the discipline "Foreign Language", business games can also be successfully used in the first and second year of high school to model various situations of intercultural communication. Furthermore, Nikolaeva and others (2016) considered the problem of the impact of innovation on the socio-cultural modernization of education.

In the works of foreign educators such as Johnson and Johnson (2009), Kagan (1994), Nunan (1992) and others, the rationale for the effectiveness of the collective activities of students is disclosed, and the types of education groups and their dynamics of development are considered. 
Additionally, co-education (CE) can be defined as a set of teaching strategies that encourage students to work together in small groups (two to five students) to optimize their education and mutual education (Jasińska, 2019). According to Baloche and Brody (2017), there can be problems with education in collaboration. It is worth agreeing with Hassanien (2006), who claims that working together in a small group can also be associated with problems, for example, tasks being unevenly distributed among the participants, poor relationships, different approaches to work, and the lack of a leader in the group. However, there are strategic ways to improve teamwork (Hassanien, 2006). According to Le, Janssen and Wubbels (2018), it is very important that teachers conduct preparatory work before the joint education procedure. That is, it is necessary to distribute roles among the members of the small group, who should be able to be attentive, listen to each other and accept different points of view. Compliance with these conditions ensures the development of a culture of effective cooperation. The researchers, Nikolaeva and Malysheva (2017), wrote about the development of teamwork skills. Moreover, Panina and others (2017) conducted research on the synergetic approach to the educational process.

\section{Materials and Methods}

The experiment involved about 340 students of the Finance and Economics Institute of Ammosov North-Eastern Federal University in the period, 2011 to 2018. The main task of the ascertaining stage of the experiment was to determine the criteria and indicators of the level of university students' development of general cultural competencies.

Troyanskaya (2008) defines a three-component structure of general cultural competencies, which include cognitive, value-orientation and communicative-pragmatic components. The cognitive component is more consistent with such forms of cultural product appropriation as researching and understanding. The various definitions of culture display their "knowledge" characteristic: "complex of knowledge" and "set of intellectual elements."

The value-orientation component involves familiarization with culture as the transfer of values through experience in the process of spiritual communication. Moreover, culture is defined as "a system of production of spiritual values," "a specific way of thinking, feeling," and "the realization of supreme values." The communicative-pragmatic component corresponds to the operational-behavioral orientation and such a method of cultural appropriation as education and co-creation. This is enshrined in the definitions of culture as a 
form of behavior, as a way of human activity, a storage system and a transmission of social experience (Troyanskaya, 2008).

To determine the cognitive component of the development of cooperation culture, a questionnaire was conducted to determine the level of students' awareness and their social and cultural knowledge.

Luskanova (1993) conducted a survey according to the method regarding motivation, using an adapted questionnaire for students.

Students of the Financial and Economic Institute of NEFU researching in the specialty "International Management" participated in the experimental work - this was an experimental group; as well as students in the field of "Economics" specialties: "Finance and credit", "Taxes and taxation" and "Labor economics" are the control group. The control group involved two courses researching according to the standard program in foreign languages for non-linguistic specialties. The students were 17-18 years old, and were divided into subgroups.

The conditions of the experiment were as follows:

In the experimental group (EG), the experiment was conducted based on the use of interactive pedagogical technologies, in the control group (CG) - based on a typical program for teaching foreign languages.

Working in small groups contributes to the development of cooperation between participants. The following were selected as the most effective interactive technologies: case method, or analysis of specific situations, project method, business and role-playing games, and interviews. To work on case studies, either ready-made scripts from an authentic English textbook were used, or scripts were created from any situation. Students were invited to analyze the situation and make quick decisions. Project presentations were created on PowerPoint. Students prepared a presentation on a regional theme in advance. In the first year, these are topics about the country of the language being studied, in the second year, they are topics about the native land - our republic. Whilst presenting, the micro-group participants tried to remember their part of the speech, since fluency of speech (fluent speaking) was considered in evaluating the overall performance. After the performance and the slide show, the rest of the group questioned the speakers. The originality of the questions was also assessed. By presenting, students acquire public speaking skills, which will undoubtedly be useful to them in their future professional activities.

Based on the goals and objectives of the experimental work to research the results of a comparative experiment, the following methods were used: 
1. Diagnostic: Boyko's method (1996) for the research of communicative tolerance; A survey of students in the experimental group. What gave them the use of active education methods in educational and extracurricular activities?

2. A questionnaire on the methodology for determining motivation by Luskanova (1993).

3. Monitoring of education quality.

4. Observation of students in the experimental and control group.

A sociometric test developed by Moreno (1956) was conducted in both groups. The test was designed to diagnose emotional connections (i.e., mutual sympathy among group members) by the following means:

- Measuring the degree of cohesion or disunity in the group;

- Revealing the relative authority of group members based on the sympathy or antipathy they evoke (i.e., leaders, stars, rejects);

- Detecting intra-group cohesive entities led by informal leaders (17).

The technique allows for making an instant cut and subsequently using the results from the dynamics of intra-group relations to restructure the groups, increasing their cohesion and effectiveness (Moreno, 1956). Preliminary data of the compiled sociological matrix showed a low level of group cohesion (0.2) in the control and experimental groups, while the indicator of good group cohesion is 0.6-0.7. There are smaller unions in the groups.

To confirm the potential for developing a culture of student cooperation, indicators of motivation and communicative tolerance of economics students were considered. These two tests were chosen because one of the important conditions for the development of a culture of cooperation is communicative tolerance, the ability to work in a team and willingness to cooperate with colleagues.

To begin the research into the communicative tolerance of undergraduate students of the Financial and Economic Institute, the communicative tolerance test proposed by Boyko (1996) was used. This test checks how subjects can accept or not accept the individuality of the people they meet, which indicates how willing they are to cooperate. According to personality substructures described by Boyko (1996), test questions were grouped according to the criteria for developing a culture of student cooperation. 
Table 1. Distribution of students by the level of communicative tolerance development at the beginning of the experiment

\begin{tabular}{|l|l|l|l|l|l|l|}
\hline \multirow{2}{*}{ Levels } & \multicolumn{2}{|l|}{ The control group - 35 people in total } & \multicolumn{2}{l|}{$\begin{array}{l}\text { The experimental group - 36 people in } \\
\text { total }\end{array}$} \\
\cline { 2 - 7 } & $\begin{array}{l}\text { Criteria } \\
\text { Cognitive } \\
\text { people / (\%) }\end{array}$ & $\begin{array}{l}\text { Value- } \\
\text { oriented } \\
\text { people } \\
(\%)\end{array}$ & $\begin{array}{l}\text { Professionall } \\
\text { y pragmatic } \\
\text { people / (\%) }\end{array}$ & $\begin{array}{l}\text { Cognitive } \\
\text { people / (\%) }\end{array}$ & $\begin{array}{l}\text { Professionall } \\
\text { yragmatic } \\
\text { people / (\%) }\end{array}$ & $\begin{array}{l}\text { Professionall } \\
\text { y pragmatic } \\
\text { people / (\%) }\end{array}$ \\
\hline High & $7 / 20 \%$ & $8 / 23 \%$ & $6 / 17 \%$ & $10 / 28 \%$ & $8 / 22.2 \%$ & $9 / 25 \%$ \\
\hline Average & $13 / 37.14 \%$ & $9 / 26 \%$ & $14 / 40 \%$ & $13 / 36 \%$ & $7 / 19.4 \%$ & $12 / 33.3 \%$ \\
\hline Low & $15 / 43 \%$ & $18 / 51 \%$ & $15 / 43 \%$ & $13 / 36 \%$ & $21 / 58.3 \%$ & $15 / 41.7 \%$ \\
\hline
\end{tabular}

As the table below illustrates, the initial level of development of the components of communicative tolerance, and therefore the culture of cooperation, is approximately the same among students in the control and experimental groups. The level of formation of cognitive, value-orientation, and professional-pragmatic criteria is somewhat low in both groups. The histograms below show the levels of formation of the three components of the development of a culture of cooperation: cognitive, value-oriented, and professional-pragmatic.

Figure 1. The level of development of the cognitive component of the culture of students' cooperation

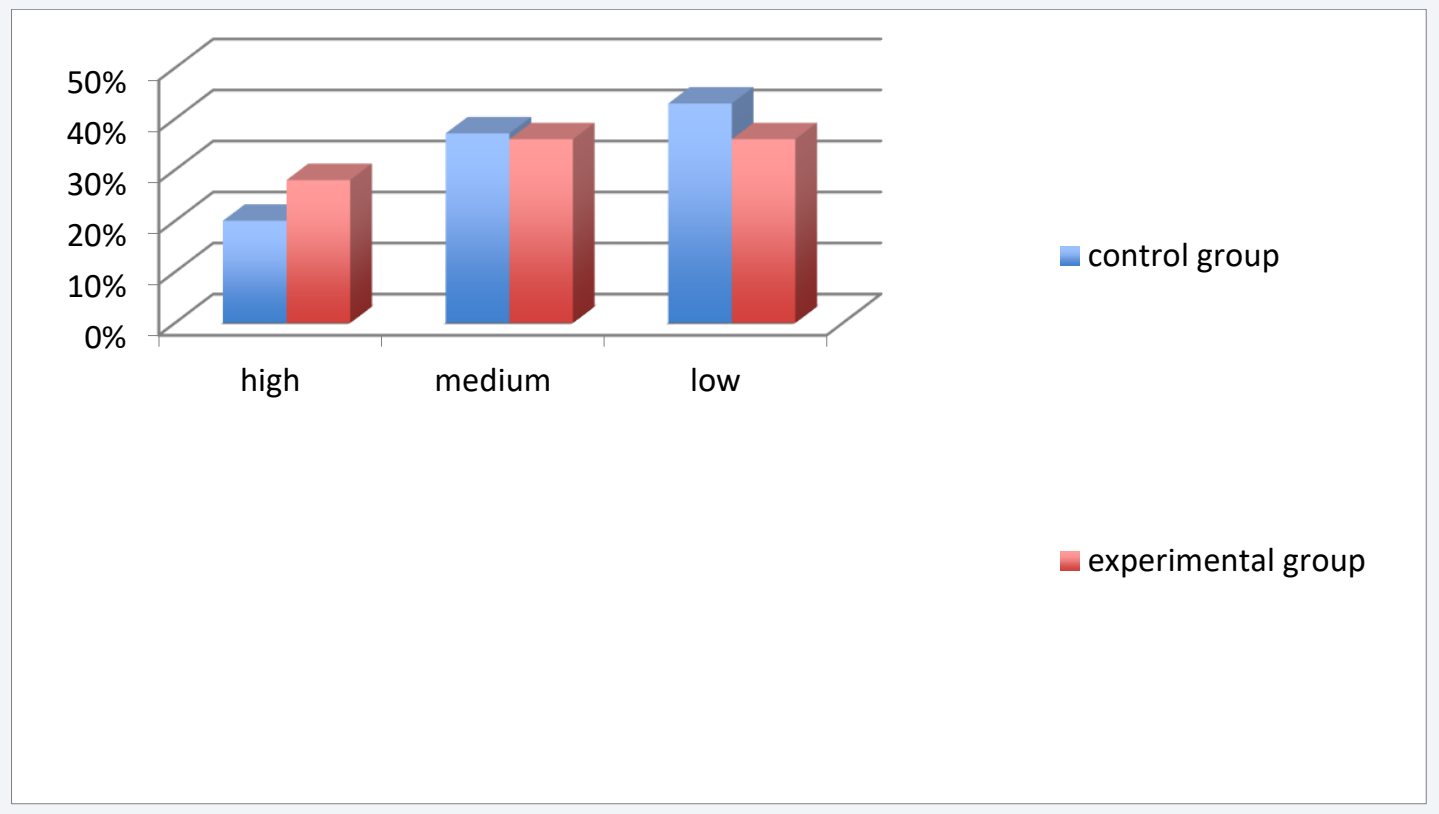


Figure 2. The development level of the value-orientation component of the culture of students' cooperation

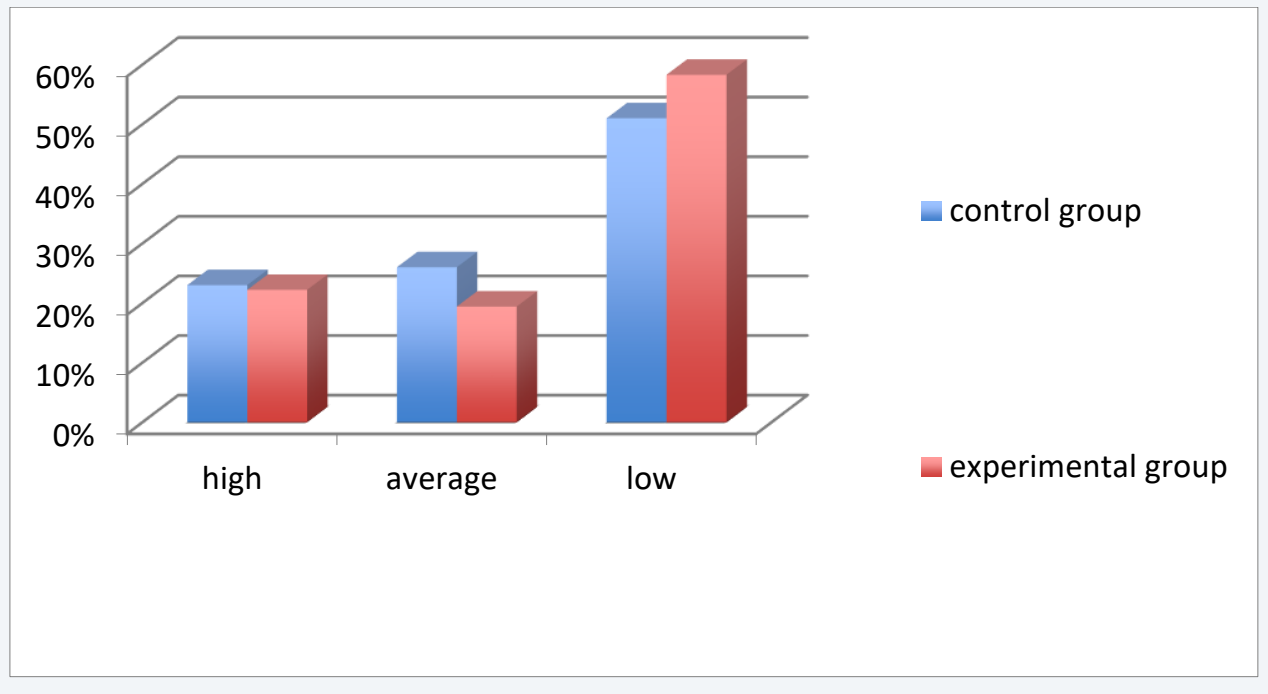

Figure 3. The level of development of the professional-pragmatic component of the culture of students' cooperation

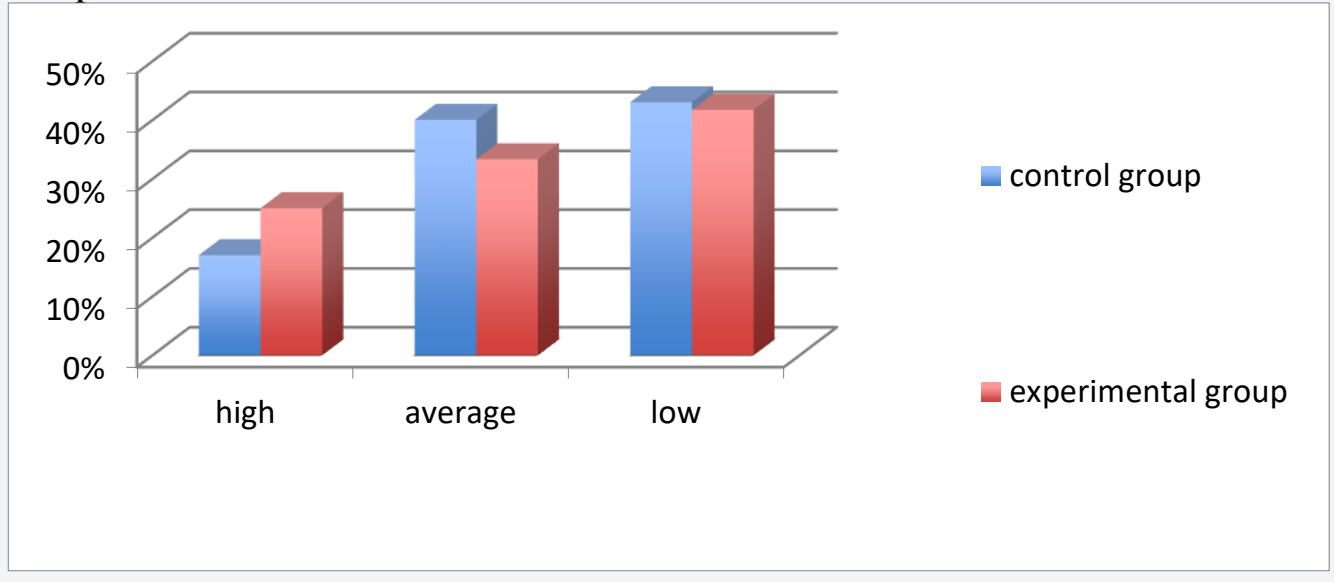

Data on the research of the level of motivation from the questionnaire by Luskanova (1993) in the control and experimental groups at the beginning of the experiment.

Table 2. Data on the research of the level of motivation on the questionnaire Luskanova (n.d.) in the control and experimental groups at the beginning of the experiment

\begin{tabular}{|l|l|l|l|l|l|l|}
\hline $\begin{array}{l}\text { FIE, course, } \\
\text { group }\end{array}$ & $\begin{array}{l}\text { First } \\
\text { level }\end{array}$ & $\begin{array}{l}\text { Second } \\
\text { level }\end{array}$ & $\begin{array}{l}\text { Third } \\
\text { level }\end{array}$ & $\begin{array}{l}\text { Fourth } \\
\text { level }\end{array}$ & Fifth level & $\begin{array}{l}\text { Q-ty of } \\
\text { students }\end{array}$ \\
\hline $\begin{array}{l}1,2 \text { courses of } \\
\text { "Economics" }\end{array}$ & 0 & 0 & 84.6 & 15.4 & 0 & 35 \\
\hline $\begin{array}{l}1,2 \text { courses of } \\
\text { EG } \\
\text { International } \\
\text { management" }\end{array}$ & 0 & 21.4 & 78.6 & 0 & 0 & 36 \\
\hline
\end{tabular}


The control group comprised second- and third-year economics students and the experimental group comprised second- and third-year students of international management. Based on these results, it can be noted that the motivation of students in the control group at the third level is $84.6 \%$, which means that they attend classes, mainly to chat with friends; the experimental group also has a predominant majority at the third level $-78.6 \%$.

Control group - 1st and 2nd-year students of the "Economics"; and the experimental group - 1st and 2nd-year students of the "International Management". Below are the levels of the questionnaire by Luskanova (1993).

First level. 25-30 points - a high level of educational motivation, educational activity.

Second level. 20-24 points - good educational motivation.

Most of the first-year students who successfully cope with educational activities have similar indicators. A similar level of motivation is average.

Third level. 15-19 points - a positive attitude towards education, but the university attracts such young people with extracurricular activities.

Fourth level. 10-14 points - low educational motivation.

Fifth level. Below 10 points - a negative attitude towards the university, maladaptation.

Table 3. Distribution of students by levels of motivation development before and after the formative experiment in the experimental and control group

\begin{tabular}{|c|c|c|c|c|}
\hline \multirow{2}{*}{ Levels } & \multicolumn{2}{|c|}{ Control groups } & \multicolumn{2}{c|}{ Experimental groups } \\
\cline { 2 - 5 } & Number of students in \% & \multicolumn{2}{c|}{ Number of students in \% } \\
\cline { 2 - 5 } & Before & After & Before & After \\
\hline High & $0 \%$ & $1 \%$ & $0 \%$ & $31 \%$ \\
\hline Average & $23 \%$ & $28 \%$ & $26 \%$ & $65 \%$ \\
\hline Low & $60 \%$ & $58 \%$ & $70 \%$ & $2 \%$ \\
\hline Very low & $17 \%$ & $13 \%$ & $3.3 \%$ & \\
\hline
\end{tabular}

Based on these results, it was noted that the motivation of students in the control group was at the third level before the experiment, which means that they attended classes, mainly to communicate with friends; in the experimental group, the majority also prevailed at the third-underestimated level. Based on the results of a stating experiment, correctional and 
developmental work was carried out, which was reflected in the subsequent stage of the experiment.

Table 4. Distribution of students by the level of development of communicative tolerance before and after the experiment

\begin{tabular}{|c|c|c|c|c|c|c|c|c|c|c|c|c|}
\hline \multirow[t]{4}{*}{ Levels } & \multicolumn{6}{|c|}{ Control groups } & \multicolumn{6}{|c|}{ Experimental groups } \\
\hline & \multicolumn{6}{|l|}{ Criteria } & \multicolumn{6}{|l|}{ Criteria } \\
\hline & \multicolumn{2}{|c|}{\begin{tabular}{|l} 
Cognitive \\
(number \\
people in \%)
\end{tabular}} & \multicolumn{2}{|c|}{$\begin{array}{l}\text { Value- } \\
\text { orientation } \\
\text { (number } \\
\text { people in \%) }\end{array}$} & \multicolumn{2}{|c|}{$\begin{array}{l}\text { Professionally } \\
\text { pragmatic } \\
\text { people (number } \\
\text { of people in \%) }\end{array}$} & \multicolumn{2}{|c|}{$\begin{array}{l}\text { Cognitive } \\
\text { (number of } \\
\text { people in \%) }\end{array}$} & \multicolumn{2}{|c|}{$\begin{array}{l}\text { Value- } \\
\text { orientation } \\
\text { (number } \\
\text { people in \%) }\end{array}$} & \multicolumn{2}{|c|}{$\begin{array}{l}\text { Professionally } \\
\text { pragmatic } \\
\text { people (number } \\
\text { of people in \%) }\end{array}$} \\
\hline & Before & After & Before & After & Before & After & Before & After & Before & After & Before & After \\
\hline High & $20 \%$ & $23 \%$ & $23 \%$ & $23 \%$ & $17 \%$ & $20 \%$ & $28 \%$ & $33 \%$ & $22.2 \%$ & $25 \%$ & $25 \%$ & $31 \%$ \\
\hline Average & $37.14 \%$ & $40 \%$ & $26 \%$ & $29 \%$ & $40 \%$ & $37 \%$ & $36 \%$ & $39 \%$ & $19.4 \%$ & $22.2 \%$ & $33.3 \%$ & $36 \%$ \\
\hline Low & $43 \%$ & $37 \%$ & $51 \%$ & $49 \%$ & $43 \%$ & $43 \%$ & $36 \%$ & $28 \%$ & $58.3 \%$ & $53 \%$ & $41.7 \%$ & $33 \%$ \\
\hline
\end{tabular}

As it can be seen from the table, in the generalizing stage, when conducting a second test - a control slice, positive dynamics was found in the work of second-year students - the indicators for cognitive, value-orientation and professionally pragmatic criteria for the development of communicative tolerance, and therefore the development of a culture of cooperation, improved.

\section{Results}

A comparative analysis of the data obtained at the beginning and end of the experiment allows for concluding that as a result of the experimental work in the experimental groups, the number of students with a low level of development of communicative tolerance decreased, the number of students with a high level of development of communicative tolerance, and, therefore, the development of a culture of cooperation increased.

In the control group, where purposeful work on the development of general cultural competencies was not carried out, the indicators did not change significantly. 
Thus, in the course of experimental work to develop a culture of cooperation among students of a non-linguistic faculty, interactive pedagogical technologies in the process of teaching English were changed and tested, and ways of their effective use in a university were substantiated.

Based on a comparative analysis of the sections according to the main indicators of the development of the cooperation culture among students of a non-linguistic faculty, it can be concluded that the experiment is effective and its positive results.

\section{Discussion}

Experimental work was carried out in the following main areas: the authors used such methods of organizing educational activities as collaboration in small groups, presenting projects in PowerPoint format on a given topic, simulations (business games), case technologies, case research, and debates. The result of this work was positive changes in the degree of students' involvement in the development of a culture of cooperation. At the end of the formative stage, it became obvious that the motivation of the students of the experimental group significantly increased.

The design form of work is one of the relevant and effective technologies that allows students to apply the accumulated knowledge in the subject and realize their creative potential. According to Malysheva (2018), project activities help students to engage in independent research activities, realize their working skills in collaboration, activate creative activities, form positive interpersonal relationships, and develop active cognitive activity. Moreover, they also lead to intra-group cohesion (Malysheva, 2018). One cannot disagree with Azhibekova (2014) that students expand their horizons and boundaries of language proficiency, gaining experience from its practical use, learn to listen to foreign language speech and understand each other in the process of speaking in defense of projects (Azhibekova, 2014).

The case method is an innovative method of university teaching that considers all the features of the subject and generates the necessary knowledge, skills, and abilities.

Interviews, role-playing, and business games can improve students' communication skills and bring simulated situations closer to future professional activities. 


\section{Conclusion}

Thus, in summary, the authors note that personality-oriented education inherently provides a differentiated approach to education, considering the intellectual development level of students, as well as their education in this subject, their abilities, and inclinations.

Competence-based education, based on a humanistic and culture-oriented methodology, defines the "system of competencies" as the goals and the result of education.

Interactive technologies for teaching students are based on innovative active methods that help to form a creative, innovative approach to understanding professional activities, develop independent thinking, and the ability to make optimal decisions in a particular situation. Interactive methods are aimed at a wider interaction of students, not only with teachers, but also with each other and the dominance of student activity in the education process.

The teacher's place in interactive classes is reduced to the direction of students' activities to achieve the objectives of the lesson.

1. The authors studied and analyzed the theoretical foundations of the development of educational and cognitive activities of students using interactive pedagogical technologies.

2. The authors selected and applied adaptive interactive pedagogical technologies that develop a culture of student cooperation, namely case technologies, role-playing games, small group presentation projects, and debates.

3. The authors organized and conducted experimental research to verify the effectiveness of the development of a culture of cooperation among students of a non-linguistic faculty.

Thus, the authors' hypothesis is true. The authors achieved the goal of the research. The results of this experimental work have shown the effectiveness of the use of communication technologies in developing a culture of cooperation among non-linguistic students.

\section{REFERENCES}

1. Abd, M.S., \& Behadili, S.F. (2019). Recognizing Job Apathy Patterns of Iraqi Higher Education Employees Using Data Mining Techniques. Journal of Southwest Jiaotong University, 54(4). http://jsju.org/index.php/journal/article/view/342

2. Al-Ameedi, R.T., Ibrahim, E.R., \& Nayef, K.J. (2019). Language Laboratory and Developing Skills in an Iraqi Secondary School. Journal of Southwest Jiaotong University, 54(5). http://jsju.org/index.php/journal/article/view/414 
3. Azhibekova, G.Zh. (2014). Innovative Methods of Teaching Foreign Languages. European Scientist, 68(2-1), 238-243.

4. Baloche, L., \& Brody, M.C. (2017). Cooperative Education: Exploring Challenges, Crafting Innovations. Journal of Education for Teaching, 43(3), 274-283.

5. Barakhsanova, E.A., \& Barakhsanov, V.P. (2018). Training Students to Use E-Learning Technology. Modern Problems of Science and Education, 6. http://www.scienceeducation.ru/ru/article/view?id=28231

6. Bespalko, V.P. (1989). Components of Educational Technology. Moscow: Pedagogy.

7. Bordovskaya, N.V., Kostromina, S.N., Darinskaya, L.A. (2020). Modern Educational Technologies. Moscow: Knorus.

8. Boyko, V.V. (1996). Emotions Energy in the Communication: Look at Yourself and at Others. Moscow: Information and Publishing House "Filin".

9. Federal Law No. 273-FZ on Education in the Russian Federation as of December 29, 2012 (as amended on December 29, 2017).

10.Federal State Educational Standard for Higher Education. http://fgosvo.ru/fgosvo/92/91/4

11.Foster, J., \& Yaoyuneyong, G. (2016). Teaching Innovation: Equipping Students to Overcome Real-World Challenges. Higher Education Pedagogies, 1(1), 42-56.

12.Hassanien, A. (2006). Student Experience of Group Work and Group Assessment in Higher Education. Journal of Teaching in Travel \& Tourism, 6(1), 17-39.

13. Ivanova, A.V., Skryabina, A.G., \& Darbasova, L.A. (2019). The Competency-Based Approach in Teaching Mathematics to Students of an Agricultural University. Higher Education Today, 8, 28-32.

14. Jasińska, M. (2019). Recognition and Description of Synergy Conditions in Team Work in View of the Grounded Theory. Entrepreneurship and Sustainability Issues, 7(1), 375-397.

15. Johnson, D.W., \& Johnson, R.T. (2009). Making Cooperative Learning Work. Theory into Practice, 38(2), 67-73.

16. Kagan, S. (1994). Cooperative Learning. San Juan Capistrano, California: Kagan Cooperative Learning.

17. Khutorskoy, A.V. (2005). Pedagogical Innovation - The Lever of Education. Eidos, http://eidos.ru/journal/2005/0910-19.htm.

18. Klarin, M.V. (1998). Innovations in World Pedagogy: Education Based on Research, Play, and Discussion (Analysis of Foreign Experience). Riga: Scientific Production Centre "Experiment".

19. Le, H., Janssen, J., \& Wubbels, T. (2017). Collaborative learning practices: teacher and student perceived obstacles to effective student collaboration. Cambridge Journal of Education, 48(1), 103-122.

20.Luskanova, A.G. (n.d.) Methodology for Determining School Motivation. https://studbooks.net/1666678/psihologiya/metodika_opredeleniya_shkolnoy motivatsii_luskanov oy

21. Luskanova, N.G. (1993). School Motivation Level Assessment. https://uchitelya.com/pedagogika/139602-anketa-ocenka-urovnya-shkolnoy-motivacii-ngluskanovoy.html

22. Malysheva, A.D. (2018). Formation of Readiness for Work in a Team of Bilingual Students (on the Example of the Republic of Sakha (Yakutia)). Perspectives of Science and Education, 4(34), 15-20.

23. Moreno, J.L. (1956). Sociometry and the Science of Man. Painswick: Beacon House.

24. National Doctrine of Education of the Russian Federation until 2025. http://med45ved.ucoz.ru/orkse/nac_doktr.pdf 
25. Nelunova, E.D. (2014). Pedagogical Foundations of Self-Development of Students in a Multimedia Educational Environment (Doctoral Thesis). Yakutsk-Yaroslavl.

26. Nikolaeva, A.D., Barakhsanova, E.A., Golikov, A.I., Alekseyeva, I.S., Egorova, R.I., Kolpakova, A.P., \& Stepanova, L.V. (2016). Linguistic Determination of the Personality. Indian Journal of Science and Technology, 9(11). http://www.indjst.org/index.php/indjst/article/view/89424

27. Nikolaeva, A.D., \& Malysheva, A.D. (2017). The Development of Students' Teamwork Skills in Foreign Language Lessons. Discussion, 5(79), 102-109.

28. Nunan, D. (1992). Research Methods in Language Learning. Cambridge: Cambridge University Press.

29. Panina, S.V., Barahsanova, E.A., Nikolaeva, A.D., Osipova, O.D., Stepanova, L.V., \& Sivseva, K.N. (2017). Synergetic Approach to the Learning Process Organization for Future Education Managers' Training at Higher Education Institutions. Espacios, 38(55), 9.

30. Richards, J.C., \& Rodgers, T.S. (1986). Approaches and Methods in Language Teaching. Cambridge: Cambridge University Press.

31. Rogers, C. (1988). Client-Centered Therapy. H.I. Kaplan, \& B.J. Sadock (Eds.), Comprehensive Textbook of Psychiatry (pp. 3-40). Baltimore, Maryland: Williams \& Wilkins.

32. Selevko, G.K. (1998). Modern Educational Technologies. Moscow: National Education.

33. Smolkin, A.M. (1991). Methods of Active Education. Moscow: Higher School.

34. Ter-Minasova, S.G. (2000). Language and Intercultural Communication. Moscow: Slovo.

35. Troyanskaya, S.L. (2008). General Cultural Competence: Experience in Defining and Structuring. Cultural-Historical Psychology, 2, 19-23.

36. Verbitsky, A.A. (2004). The Competency-Based Approach and the Theory of Contextual Education. Moscow: Research Center for Continuing Education and Professional Reeducation.

37.Vygotsky, L.S. (2019). Thinking and Speech: Psychological Research. Moscow: National Education.

38. Zimnyaya, I.A. (2006). Key Competencies - A New Paradigm of the Result of Modern Education. Eidos. http://www.eidos.ru/journal/2006/0505.htm

\section{SOBRE OS AUTORES:}

\section{Avgustina Vasilievna Ivanova}

Ammosov North-Eastern Federal University, Pedagogical Institute, Department of Primary Education, Yakutsk, Republic of Sakha (Yakutia), 58 Belinsky St., Russian Federation, Postal Code: 677000. Corresponding Author Email: Ivaya1@bk.ru

(iD http://orcid.org/0000-0003-4182-4228 


\section{Lena Anatolievna Grigorieva}

Ammosov North-Eastern Federal University, Institute of Foreign Philology and Regional Studies, Department of Foreign Languages, Technical and Natural Sciences, Yakutsk, Republic of Sakha (Yakutia), 48 Kulakovsky St., Russian Federation, Postal Code: 677000. E-mail: professor-grigorieva67@gmail.com

iD http://orcid.org/0000-0003-0138-2031

\section{Oksana Nikolaevna Ivanova}

Yakutsk State Agricultural Academy, Department of Social and Humanitarian Disciplines of Economic Faculties, Yakutsk, Republic of Sakha (Yakutia), 15 Krasilnikova St., Russian Federation, Postal Code: 677007. E-mail: o.n.ivanova@mail.ru

iD http://orcid.org/0000-0003-4050-649

\section{Natalia Vitalievna Lysanova}

Ammosov North-Eastern Federal University, Institute of Foreign Philology and Regional Studies, Department of Foreign Languages in Technical and Natural Sciences, Yakutsk, Republic of Sakha (Yakutia), 48 Kulakovsky St., Russian Federation, Postal Code: 677000. E-mail: n-lysanova@mail.ru

iD http://orcid.org/0000-0002-5194-8796

\section{Lyudmila Alekseevna Gavrilieva}

Ammosov North-Eastern Federal University, Institute of Foreign Philology and Regional Studies, Department of Foreign Languages, Technical and Natural Sciences, Yakutsk, Republic of Sakha (Yakutia), 48 Kulakovsky St., Russian Federation, Postal Code: 677000. E-mail: gavrilieva.1.a@rambler.ru

iD http://orcid.org/0000-0001-6435-5853 